AperTO - Archivio Istituzionale Open Access dell'Università di Torino

\title{
RECEPTOR TYROSINE KINASES AS TARGET FOR ANTI-CANCER THERAPY
}

\section{This is the author's manuscript}

Original Citation:

Availability:

This version is available http://hdl.handle.net/2318/92859

since

Publisher:

Bentham Science Publishers BV:PO Box 7917, Exec Ste Y 26, Saif Zone Sharjah Uae:011 97165571132 ,

Terms of use:

Open Access

Anyone can freely access the full text of works made available as "Open Access". Works made available under a Creative Commons license can be used according to the terms and conditions of said license. Use of all other works requires consent of the right holder (author or publisher) if not exempted from copyright protection by the applicable law. 


\title{
Receptor Tyrosine Kinases as Target for Anti-Cancer Therapy
}

\author{
S. Brunelleschi, L. Penengo, M.M. Santoro and G. Gaudino*
}

University of Piemonte Orientale “A.Avogadro”, Department of Medical Sciences, Novara, Italy

\begin{abstract}
Receptor tyrosine kinases (RTKs) are cell surface transmembrane proteins responsible for intracellular signal transduction. They are expressed in several cell types and, after activation by growth factor binding, trigger a series of intracellular pathways, leading to a wide variety of cell responses (e.g., differentiation, proliferation, migration and invasion, angiogenesis, survival). Over-expression and/or structural alteration of RTKs family members are often associated to human cancers and tumor cells are known to use RTK transduction pathways to achieve tumor growth, angiogenesis and metastasis. Therefore, RTKs represent pivotal target in approaches of cancer therapy. A number of small molecules acting as RTK inhibitors have been synthesized by pharmaceutical companies and are under clinical trials, are being analyzed in animal models or have been successfully marketed. Liganddependent downregulation of RTKs is a critical step for modulating their activity and the adaptor Cbl has been indicated as the key protein involved in negative regulation of RTKs, such as EGF and HGF receptors. These data suggest novel potential pharmacological targets for the treatment of human malignancies associated to oncogenic activation of RTKs.
\end{abstract}

Keywords: Growth Factor Receptor - Tyrosine kinase - Tyrosine kinase Inhibitor - Signal transduction - Cancer Downregulation

\section{RECEPTOR TYROSINE KINASES (RTKS)}

Growth factors are extracellular signals that regulate cell proliferation and differentiation. The vast majority of them, such as Platelet-Derived Growth Factor (PDGF), Epidermal Growth Factor (EGF), Fibroblast Growth Factor (FGF), Vascular Endothelial Growth Factor (VEGF), Hepatocyte Growth Factor (HGF) and others, bind to receptors with tyrosine kinase activity (RTKs), which have been often involved in human cancers. RTKs consist of an extracellular ligand binding domain, usually glycosylated, connected to the cytoplasmic domain by a single transmembrane helix. The intracellular domain contains a conserved protein tyrosine kinase core and additional regulatory sequences that undergo phosphorylation. The extracellular domain displays different structural elements, such as one or more copies of Immunoglobulin-like domains, fibronectin type III-like repeats, EGF-like domains, cysteine-rich regions and other features [1].

Based on their structural extracellular characteristics, RTKs can be classified into approximately twenty families. Some examples of receptors altered in human cancer are listed here: family I, EGF receptor and its homologs, with two cysteine-rich domains; family III, PDGF receptors, with five Immunoglobulin-like domains; family IV, FGF receptors, with three Immunoglobulin-like domains; family

*Address corresponding to this author at the University of Piemonte Orientale "A.Avogadro", Department of Medical Sciences, via Solaroli, 17, 28100 Novara, Italy; Email: giovanni.gaudino@unipmn.it
V, VEGF receptors with seven immunoglobulin domains; family VI, the HGF receptor and its homologs, that have a heterodimeric structure; family XIV, the Ret receptor with a Cadherin repeat and a cysteine-rich region. RTKs belong to a large family of proteins with a wide range of functions, including proliferation, migration, differentiation, morphogenesis and metabolism [1].

The main hallmark of this family is an intrinsic enzymatic activity that catalyzes the transfer of the $\gamma$ phosphate of ATP to tyrosine residues in protein substrates. With the only exception of the insulin receptor family, all known RTKs are monomers in the cell membrane. Ligand binding in the extracellular domain induces receptor dimerization and trans-phosphorylation of specific tyrosine residues located in the cytoplasmic portion of the receptor [2]. The currently accepted model for RTKs dimerization proposes that active dimers exist even in the absence of ligand binding, since auto/trans-phosphorylation of RTKs can be obtained either by using inhibitors of protein tyrosine phosphatases (PTPs) or by receptor over-expression. The effect of ligand binding to the extracellular domain of the receptor stabilizes the formation of active dimers and consequently the activation of the kinase activity.

Ligand-induced dimerization is a process required during RTKs activation, even if different ligands can use different strategies to induce this active dimeric condition. Receptor dimerization is further stabilized by additional receptorreceptor interactions [3-4]. In the case of homodimeric growth factors, as PDGF, the receptor becomes dimerised by direct interaction with the ligand. In some cases, an accessory protein is required to complete the ligand-mediated 
receptor dimerization. As an example, heparin or heparan sulphate proteoglycans play an essential role in stabilizing the FGF and HGF receptor dimers [5-6].

In recent years, structural studies by X-ray crystallography have been essential to reveal the molecular mechanisms by which RTKs become activated, following dimerization and tyrosine auto-phosphorylation [7]. The crystal structure of the insulin receptor tyrosine kinase in both active and inactive conformation revealed a twofold mechanism for activation. In the inactive state, the activation loop (A-loop) of the kinase domain occupies the active site, blocking the access to substrate and ATP. Once phosphorylated in three tyrosine residues within the loop (Y1158, Y1162, Y1163), it undergoes a major conformational change moving the activation loop away from the active site, resulting in free access for ATP and protein substrates to the kinase active site [8-9]. In this model, phosphorylated Y1163 is the key regulator in stabilizing the conformation of the activation loop, whereas pY1158 is completely exposed to solvent, suggesting availability for interaction with downstream signaling proteins. The importance of this alternative docking site is elucidated in the case of APS-SH2B adapter family, that selectively bind tyrosine residues in the activation loop of RTKs, acting as negative regulator of receptor signaling [10].

The crystal structure of Fibroblast Growth Factor Receptor 1 (FGFR1K) revealed several differences from the tyrosine kinase domain of insulin receptor. Residues in the A-loop of FGFR1K appear to interfere with substrate peptide binding, but not with ATP binding, providing a second and perhaps more general auto-inhibitory mechanism for RTKs [11].

\section{Mechanisms of RTKs Signal Generation}

As stated above, upon binding to their ligands, RTK molecules dimerise and undergo autophosphorylation on specific tyrosine residues, generally located in the noncatalytic regions of the receptor molecule. In turn, these phosphotyrosines and their adjacent sequences specifically recruit downstream signaling molecules, generally through SH2 (Src-Homology 2) or PTB (PhosphoTyrosine Binding) domains, causing their subsequent phosphorylation. Many of these proteins contain intrinsic enzymatic activities ( $\mathrm{Src}$ kinases, Shp2 PTP, PLC- $\gamma$, or Ras-GAP) and/or protein modules that mediate interactions with other proteins, phospholipids or nucleic acids. A number of protein modules have been shown to be involved in cellular signaling downstream of RTKs and of other cell surface receptors, mediating either constitutive or ligand-dependent associations [12].

Recruitment of proteins onto RTKs leads to their activation by virtue of three mechanisms: a) recruitment to the plasma membrane, i.e. to a subcellular compartment where substrates are available; b) allosteric changes induced by phosphotyrosine-directed protein-protein interactions; c) direct phosphorylation on specific tyrosine residues. Ultimately, the definition of the cellular response is governed by coupling to diverse signaling molecules which create a complex network of molecular interaction cascades. Signals that stimulate different mitogen-activated protein (MAP) kinases are of special importance in the control of cell growth, differentiation and other responses, because they provide a link to Transcription Factor(s) activation and induction of gene expression [13].

\section{RTK Signaling by Heterodimeric Aggregates}

Recent insights have strongly enhanced the diversity of possible cell response modulation parameters. These include the realization of heterologous RTK interaction. The formation of heterodimeric receptor complexes, which are composed of closely related RTK members, can contribute to enhance or modify signal generation. Heterodimer formations have been observed for PDGF $\alpha$ and $\beta$ receptors, the EGF receptor family, the FGF receptor family, the Neurotrophin receptor family, the HGF receptor family and raise the possibility that heterodimer formation may be involved in a wide range of cellular responses [2]. In such a context, the different affinity of a ligand for distinct receptor combinations might have a fundamental importance in signal modulation.

\section{RTK Activation by Ligand-Independent Mechanisms}

The activation of RTKs can also occur in a ligandindependent manner. Mutation in the extracellular as well as in the kinase domain of a given RTK may result in its constitutive activation. This may occur even in the ligand absence, due to novel inter-molecular contacts that facilitate receptor dimerization and activation. Alternatively, mutations occurring in the kinase domain give rise to activated receptor, by alteration of the activation loop, the ATP binding site of the glycine loop or of the substrate binding pocket. Constitutively activated receptors are associated with a number of human diseases, Ret and Met point mutations (see below) being particularly involved in neoplastic syndromes [1].

\section{Mechanism of Signal Attenuation and Termination}

The activity of RTKs must be tightly regulated and properly balanced in order to mediate their normal cellular tasks and many physiological processes. Generations of aberrant forms, over-expression and/or dysfunction of RTKs are associated to several diseases, including cancer.

Different mechanisms have been developed for attenuation and termination of RTKs signaling. These include different strategies: a) expression of antagonistic ligands, (EGF-like protein Argos in Drosophila that binds to EGF receptor and, by competing with Spitz for the receptor binding, inhibits EGFR activity [14]); b) inhibition of tyrosine kinase activity of the receptor either by receptor modification, such as serine phosphorylation (PKC-mediated phosphorylation of EGFR strongly inhibits EGF binding to the extracellular domain of the EGFR [15]), or by direct binding to the tyrosine kinase domain through $\mathrm{SH} 2$ domains 
(SOCS family functions as a negative regulator for feedback inhibition in response to cytokine stimulation [16]), as well as by competitive inhibitors of ATP binding to tyrosine kinase (see below); c) inhibition by PTPs (Protein-Tyrosine Phosphatases), which plays a major role in RTK negative regulation [17]; d) ligand-induced endocytosis of ligandreceptor complexes, which leads to attenuation of receptor signaling and could therefore be considered as a tumorsuppressor pathway [18].

Given the relevance of activated RTKs in cancer, one could expect that PTP genes would have been found as tumor suppressor genes. However, this does not seem to be the case in general, even if it has been reported that the PTEN/MMAC gene (which is mutated in some sporadic cancers and in the Cowden's hamartoma cancer syndrome) encodes a member of the dual-specificity protein phosphatase family [19].

\section{RTKS SELECTIVE ANTICANCER DRUGS: AN UPDATE}

This chapter is intended to give a review on the development of selective tyrosine kinase inhibitors as anticancer drugs. Other important approaches, such as antibodies against the receptor and/or ligand, soluble forms of growth factor receptors, ribozymes, antisense ribonucleotides, phosphatase inhibitors or SH2/SH3-directed agents etc., will not be discussed here.

Selected tyrosine kinase inhibitors, particularly attractive for some physico-chemical and/or pharmacokinetic features, will be summarized. These are recently approved and marketed drugs for cancer treatment, agents currently under clinical trials or molecules with significant potential to treat clinical cancer. These agents will be presented according to RTK subfamily that they inhibit.

Current cancer treatment relies on administration of cytotoxic drugs that act on both tumor and normal cells. Usually the therapy consists of the combination of two or more agents, also in an effort to reinforce the anti-tumoral efficacy and to delay and/or to avoid development of drug resistance.

In the past twenty years an increasing number of studies have been directed to the molecular mechanisms of neoplastic transformation and tumor progression. In particular, most of our knowledge on the mechanisms of cell transformation is focused on the signaling pathways leading to cell proliferation, migration and survival, evoked by intracellular tyrosine kinase activity. Moreover, as stated above, the molecular structure of the tyrosine kinase domain has been elucidated by X-ray crystallography. This enabled the search for more selective and less cytotoxic drugs, from naturally derived to synthetic compounds, based on molecular modeling of the tyrosine kinase domain of individual membrane RTKs.

Growing evidences point to new discovered compounds that have been developed and/or are under testing, as clinically useful cancer chemotherapeutic agents, specific for some of the several RTKs families. In the following section, recent advances on this topic will be summarized.

\section{Tyrosine Kinase Inhibitors of EGF Receptor Family}

The EGF receptor was the first discovered member of the wide HER/erbB family of membrane RTKs, including HER2-neu/erbB2 and heregulin or neuregulin receptors HER3/erbB3 and HER4/erbB4. A large number of solid tumors (gastrointestinal tract, non-small cell lung, breast, prostate, bladder and ovarian carcinomas, head and neck cancers, glioblastoma) display overexpression or structural alteration of EGF receptor family members, associated to poor prognosis and, in some cases, to resistance to hormone therapy, cytotoxic agents and radiotherapy [20-23]. The most common EGF receptor mutant found in human cancer is EGFRvIII [24]. It is a truncated receptor lacking domains I and II of the extracellular portion and being incapable of ligand binding: however, it shows a constitutively activated tyrosine kinase domain that stimulates cell proliferation independently of ligand interaction [21]. The main signaling pathways of this family of receptors are Ras-MAPK, mainly involved in cell proliferation and PI-3 kinase/Akt, responsible for cell cycle progression and survival from apoptosis [23, 25].

Due of the relevance of these RTKs to the development of human cancer, pharmacological researches focused for several years on inhibitors of the tyrosine kinase activity, responsible for the receptor functions, to be developed as potential anticancer drugs. Moreover, because of the multiple ligands for a given receptor, targeting of the kinase is a particularly advantageous approach to inhibit these receptors. Most of these agents are low-molecular-weight molecules that inhibit tyrosine trans-phosphorylation of the intracellular moieties in homodimerised receptors, by interfering with the kinase domain ATP binding site [26].

These agents were initially identified as naturally derived molecules, the isoflavone genistein being the first discovered. It is an ATP competitive inhibitor, but it acts at high concentrations in vitro and it is not selective for the EGF receptor. Moreover it also exerts actions independent of tyrosine kinase inhibition, such as estrogen receptor binding and modulation [27]. Selectivity of genistein has been ameliorated by generation of a conjugate made of human recombinant EGF fused to genistein. This showed good tolerability in animals and enhanced anti-tumoral activity on human tumor xenografts in immunodeficient (SCID) mice [28]. Other natural inhibitors include herbimycin A, quercetin and herbstatin. Notably, quercetin has been the first tyrosine kinase inhibitor used in a phase I clinical trial on cancer patients [29].

More interesting molecules belong to three classes of compounds: 4-anilinoquinazolines, 4-[aryl-alkyl-amino] pyridopyrimidines, 4-phenylaminopyrrolo-pyrimidines. On these synthetic drugs the pharmaceutical industry concentrated many efforts to prepare potent anticancer drugs for clinical development. These agents have variable selectivity for EGF receptor family tyrosine kinases and different physico-chemical characteristics. Among the several 
EGF receptor tyrosine kinase inhibitors, CI-1033, OSI-774, PKI-166 and ZD1839 have been used in clinical trials at different phases.

ZD1839 ["Iressa", chemical name: 4-(3-chloro-4fluoroanilino)-7-metoxy-6-(3-morpholinopropoxy) quinazoline] is a low-molecular-weight synthetic compound that can be administered per os, either alone or in combination with cytotoxic agents, with an excellent tolerability, diarrhea and acneiform skin rash being the most frequently adverse events. Anticancer activity has been demonstrated for colorectal, ovarian, non-small cell lung, renal, head and neck and some prostate tumors $[30,31]$. The antiproliferative effects of ZD1839 in combination with cytotoxic drugs (e.g., cisplatin, carboplatin, paclitaxel, doxorubicin, etoposide, topotecan etc.) have been evaluated on different human cancer cell lines, co-administration of ZD1839 markedly enhancing anti-tumor activity of all cytotoxic drugs tested [32-34]. ZD1839 is able to inhibit in vitro the tyrosine kinase activity of EGF receptor with an $\mathrm{IC}_{50}$ of 23 $\mathrm{nM}$, whereas more than hundredfold higher concentrations are required to inhibit other similar kinases (HER2) or those of other families (KDR, Flt-1) [35]. It delays cell cycle progression by disrupting the regulation of cyclin-dependent kinase-2 (CDK2) in some human tumor cultured cells [35].

Interestingly, other specific quinazoline derivatives (AG1478 and AG-1517) not only compete with ATP, but in addition induce the sequestration of the receptor into inactive, unphosphorylated dimers in A431 carcinoma cells. Moreover, these drugs cause ligand trapping into these inactive complexes, reducing the availability of active growth factor molecules [36, 37].

OSI-774 [chemical name:6,7-bis(2-metoxy-ethoxy)quinazolin-4-yl-(3-ethynylphenyl)amine] is a quinazoline derivative, reversible ATP competitive inhibitor, that provokes cell cycle arrest in G1. It has been demonstrated to induce apoptosis in a colon cancer cell line [26]. It can be administered orally on a daily schedule, with low toxicity except for diarrhea and acneiform skin rash, as in the case of ZD1839. It showed anticancer activity or long periods of stable disease in patients with advanced solid tumors, such as colorectal, breast, kidney, non-small cell lung and other epidermoid malignancies [38]. OSI-774 is even more active than ZD1839, its $\mathrm{IC}_{50}$ being $2 \mathrm{nM}$ on inhibition of purified EGFR kinase activity. It is now in phase II trial for the treatment of advanced head and neck, non-small cell lung and ovarian tumors.

CI-1033 is the water soluble analog of PD183805, [chemical name: 4-(-3-(chloro-4-fluoro-phenylamino)-7-(3morpholin-4-yl-propoxy)-quinazolin-6-yl)-acrylamide dihydrochloride]. It is an irreversible inhibitor of all members of the EGF receptor family (pan-erbB inhibitor). Also for this drug diarrhea and skin rash are the typical adverse effects [39]. It has been demonstrated that CI-1033 inhibits Akt activation induced by tyrosine kinases of the erbB family. In combination with gemcitabine treatment, it induces a strong pro-apoptotic effect, which is evoked by the tyrosine kinase inhibitor alone in the presence of constitutive p38 MAPK activation [40].
PKI-166 [chemical name: 4-(R)-phenethylamino-6(hydroxyl)phenyl-7H-pyrrolo[2,3-d]-pyrimidine] is a tyrosine kinase inhibitor that revealed as a valid therapeutic tool for the treatment of human pancreatic carcinoma, alone or in combination with gemcitabine. It inhibits growth and metastasis of pancreatic carcinoma xenografts in nude mice, which are associated with a significant reduction in tumor production of VEGF and IL-8. This reduction correlates with decrease in microvessel density and with induction of extensive apoptosis of tumor-associated endothelial cells $[41,42]$.

Recently, a series of novel dual ErbB2/EGF receptor tyrosine kinase inhibitors have been proposed as potential therapeutic agents. These are quinazoline and pyridopyrimidine derivatives. The dual inhibition capacity is due to the 4-anilino substitutions of previously characterized drugs. These agents were investigated by tumor xenografts experiments (where they exerted a significant tumor growth inhibition already at $10 \mathrm{mg} / \mathrm{kg}$ per os) and were well tolerated by the animals even at higher doses. The most potent of these new compounds was GW2974 [43].

\section{TYROSINE KINASE INHIBITORS OF THE PDGF FAMILY (PDGF RECEPTOR, C-KIT)}

\section{Tyrosine Kinase Inhibitors of PDGF Receptor}

PDGF (Platelet-derived growth factor), originally identified in whole blood serum and purified from platelets, is a family of disulfide-bonded dimeric isoforms [44]. Traditionally, the PDGF isoforms consisted of homo- and heterodimers of structurally similar A- and B-polypeptide chains; two novel members of this family, namely PDGF-C and PDGF-D, have been recently identified [45]. Many different cell types are able to synthesize PDGF; synthesis is often increased in response to external stimuli, i.e., hypoxia, thrombin or stimulation with various growth factors and cytokines [44, 45]. PDGF isoforms exert their biological effects by binding to and activating two structurally related tyrosine kinase receptor, namely the $\alpha$ - (PDGF-A, -B and $-\mathrm{C})$ and the $\beta$-receptor (PDGF-B and -D) [45].

Activation of PDGF receptors leads to stimulation of cell growth, chemotaxis, changes in cell shape and motility. PDGF and its receptors play a major role in embryonic development, wound healing, regulation of vascular system. Overexpression of PDGF has been linked to several disorders, and especially, atherosclerosis and fibrotic conditions [44]. The sis oncogene of simian sarcoma virus (SSV) is related to the $\beta$-chain of PDGF $[46,47]$ and SSV transformation involves autocrine stimulation by a PDGFlike molecule [48, 49]. Many different human tumors express elevated levels of PDGF and cognate receptors, correlating with poor response to chemotherapy and shorter survival times [50]. Thus, the finding that PDGF induces transformation and malignancy in experimental systems suggests a role for PDGF in the development of spontaneous tumors in man $[50,51]$.

Therefore, experimental research was settled to design synthetic agents able to block the activity of the complex 
between PDGF and its receptor. Among the different available molecules, interest has been largely focused to PDGF receptor inhibitors STI571, SU 101 and GFB-111 $[50,51]$.

The tyrosine kinase inhibitor STI571 (see below), also known as imatinib mesylate, not only blocks Bcr-Abl and cKit, but is also a potent inhibitor of the PDGF receptor kinase and is currently being evaluated for treatment of PDGF-responsive tumors such as prostate cancer [52].

SU101 (or leflunomide), originally described and developed as an inhibitor of dihydroorotate dehydrogenase (a key enzyme of the pyrimidine pathway), has been marketed in 1998 as an anti-rheumatoid arthritis agent [53]. However, SU101 was also shown to inhibit, at micromolar concentrations, different tyrosine kinases [54, 55]. It was demonstrated as an effective inhibitor of PDGF-mediated signal transduction and tumor growth [56] and as an EGF receptor inhibitor [57]. Leflunomide/SU101 yields an active metabolite (SU0020 or A771726), that inhibits COX-2 activity in vitro [58]. SU101 was well tolerated in a Phase I study in cancer patients, when administered as a 24-hour continuous i.v. infusion at doses up to $443 \mathrm{mg} / \mathrm{m}^{2} /$ week [59]. At this dose, the plasmatic concentrations of its metabolite were able to block PDGF- and EGF- receptor signaling, as well as pyrimidine biosynthesis [59]. Mild nausea, vomiting and fever (but no hemolysis and hematopoietic toxicity) were observed in about $20 \%$ of all courses given [59]. SU 101 has been reported to be in advanced trials for multiple solid tumor types, although some problems and uncertainties have arisen [51].

GFB-111 (Growth Factor Binder-111) is the most representative of a novel series of protein surface binding agents, composed of a central calix[4]arene scaffold to which are attached four peptide loop domains [50,60]. Several peptide loop sequences have been synthesized to obtain molecules with negative and positive charged regions as well as hydrophobic regions, capable of binding to complementary areas on the target growth factor $[50,60]$. A series of hydrophobic and positively charged aminoacids in loops I and III of one monomer and loop II of the head-to tail linked second monomer represent the critical residues for PDGF binding to its receptor [50]. As far as VEGF is concerned, its receptor binding regions are composed of hydrophobic and negatively charged regions [61], whereas EGF has a completely different structure to PDGF and VEGF [62]. Therefore, given the variance of the receptor binding domains of these three growth factors, this approach is suitable to design molecules able to bind selectively to a target growth factor. Indeed, the negative charged and hydrophobic portions of GFB-111, by matching the positive and hydrophobic surface of PDGF, are responsible for its selectivity versus PDGF. GFB-111 binds to PDGF, prevents the binding of PDGF to its receptor tyrosine kinase, blocks PDGF-induced receptor autophosphorylation, activation of Erk1 and Erk2 kinases and DNA synthesis [60]. It is a potent and selective PDGF antagonist $\left(\mathrm{IC}_{50}=\right.$ $250 \mathrm{nM}$ ), it inhibits also VEGF-induced Flk-1 tyrosine phosphorylation $\left(\mathrm{IC}_{50}=10 \mu \mathrm{M}\right)$, whereas $\mathrm{IC}_{50}$ values $v \mathrm{~s}$ EGF, IGF-1 and FGF are above $100 \mu \mathrm{M}$ [60]. GFB-111 $(50-200 \mathrm{mg} / \mathrm{kg} /$ day) is demonstrated to inhibit tumor growth (human glioblastoma and human lung adenocarcinoma) and angiogenesis in nude mice, suggesting its possible value in treating a wide spectrum of human cancers [60].

\section{Tyrosine Kinase Inhibitors of SCF (Stem Cell Factor)- Receptor (c-Kit)}

The c-Kit receptor, a transmembrane $145-\mathrm{kDa}$ protein, is essential for the development of normal hematopoietic cells and has been suggested to play a significant role in acute myeloid leukemia [63]. Binding of Stem Cell Factor (SCF) to the c-Kit receptor results in autophosphorylation on tyrosine and activation of its kinase activity. In mice, natural occurring mutations at $S t l$ locus (which encodes SCF) or in the c-Kit receptor result in macrocytic anemia, dramatic decrease in mast cells, alterations in gametogenesis and melanogenesis [64]. Although it is not expressed in mature peripheral blood cells, c-Kit is normally expressed in hemopoietic cells, melanocytes, germ cells as well as a variety of solid tumors [65]. Co-expression of both c-Kit and its ligand SCF has been reported in myeloid leukemia, neuroblastoma, breast tumors, colon tumors, gynecological tumors, testicular germ cell tumors and at least $70 \%$ of SCLC (small cell lung cancer) cell lines and tumor specimens [66].

SU 5416 and SU6668, besides inhibiting Flk-1/KDR (see below), dose-dependently inhibit c-Kit kinase activity in MO7E cells [67]. Both compounds inhibit tyrosine phosphorylation of c-Kit as well as SCF-induced proliferation, $\mathrm{IC}_{50}$ values being 0.1 and $0.29 \mu \mathrm{M}$ for $\mathrm{SU}$ 5416 and SU 6668, respectively, and also induce apoptosis [67]. Their therapeutic effect could therefore be dual: inhibition of c-Kit may reduce blast proliferation and overall cell number, while inhibition of Flk-1/KDR-mediated signaling in endothelial cells, may reduce either the proliferation of endothelial cells than the production of growth factor, such as CSF, stimulating the proliferation of blast cells [67].

Similar results were obtained in leukaemic blasts from cKit positive patients [67]. Moreover, SU 5416 treatment has not been associated with myelodepression or anemia [68] and indolinone derivatives related to these SU compounds killed neoplastic mast cells expressing constitutively activated forms of c-Kit [69].

Other tyrosine kinase inhibitors that block SCFdependent proliferation have been described. AG1295 and AG1296, quinazoline derivatives competing for ATP binding, inhibit SCF-mediated Kit activation and SCFmediated proliferation of SCLC cells [70]. AG1295 also inhibit the tyrosine kinase activity of PDGF and FLT3, receptors closely related to c-Kit, and is selective cytotoxic to acute myeloid leukemia blasts that present internal tandem duplication mutations in the juxtamembrane region of the cytoplasmic domain of FLT3 [71].

STI571 (see also below), a 2-phenylaminopyrimidine derivative originally established as an ATP competitive inhibitor of Bcr-Abl [72], is able to inhibit SCF-stimulated cell growth, c-Kit autophosphorylation, activation of 
mitogen-activated protein (MAP) kinase and activation of Akt with an $\mathrm{IC}_{50}$ of $100 \mathrm{nM}[73,74]$.

Thus, inhibition of c-Kit as well as PDGF receptor could account for clinical efficacy of STI571 in chronic myeloid leukemia, as well as for its toxic side-effects (neutropenia), as c-Kit and PDGF receptor are both believed to play important roles in maintaining bone marrow stromaprogenitor cells interactions $[75,76]$.

Substituted indolinones have been identified as suitable chemical structures to design tyrosine kinase inhibitors. By modifying the substituents on the pyrrole and oxindole rings it is possible to modulate the potency of selectivity of these compounds for inhibition of certain kinases [77, 78]. These compounds have been demonstrated to be particularly effective in inhibiting the kinases of the PDGF receptor family that includes VEGF receptor and Kit. Among these compounds, SU 6597 seems to be more selective for the cKit kinase [66], offering a new approach to inhibit c-Kitmediated proliferation of SCLC, gastrointestinal stromal tumors, seminomas and leukemias.

\section{Tyrosine Kinase Inhibitors of VEGF Receptor Family}

VEGF (Vascular Endothelial Growth Factor) is a family of at least six 32 to $43 \mathrm{kDa}$ proteins: VEGF-A (or VEGF), PIGF, VEGF-B, VEGF-C, VEGF-D and VEGF-E (orph virus VEGF) [79]. VEGF is expressed in different tissues (e.g., brain, liver, spleen, and kidney) and cells, having a more restricted expression on endothelial cells than on other types [79]. VEGF regulates vascular permeability in vivo and has a pronounced angiogenic effect in vitro. Different growth factors and cytokines, including PDGF, EGF, TNF- $\alpha$, TGF$\beta$ and IL- $1 \beta$ induce VEGF mRNA transcription; therefore, VEGF can also function as a mediator for indirect-acting angiogenic factors [80]. VEGF levels are regulated by tissue oxygen tension, hypoxia inducing VEGF expression and normoxia down-regulating VEGF production $[81,82]$.

Two high-affinity binding sites for VEGF, namely VEGFR-1 (or Flt-1) and VEGFR-2 (KDR, human homologue or Flk-1, murine homologue: fetal liver kinase1 ), have been identified on endothelial cells, receptor gene expression being regulated by hypoxia [83].

These two tyrosine kinase receptors seem to mediate different biological VEGF activities. While VEGFR-2 (KDR) is known to induce endothelial cell proliferation, migration, differentiation, tube formation, increase in permeability and maintenance of vascular integrity [84], VEGFR-1 (Flt-1) has been implicated in monocyte/macrophage migration and is thought to be the main receptor to which VEGF binds in hematopoietic progenitor cells $[85,86]$. On the contrary, VEGFR-3 (Flt-4) is not a receptor for VEGF, but binds VEGF-C and VEGFD [79].

Different observations strongly support the major role played by VEGF and its receptors in tumor angiogenesis, tumor growth and metastasis [87, 88]. Elevated VEGF levels are often measured in sera from cancer patients, VEGF production being closely associated with poor prognosis
[89]. Even more important is the observation that disruption of VEGF signaling through Flk-1/KDR potently inhibits tumor growth in animal models: a dominant-negative Flk-1 mutant not only blocked endothelial cell proliferation, but also inhibited the growth of eight out nine tumor cell lines implanted subcutaneously into athymic mice and markedly reduced vessel density in tumors $[90,91]$. On these bases, neutralizing antibodies to VEGF and small molecules able to inhibit Flt-1/KDR tyrosine kinase activity have been developed as potential anti-cancer drugs.

The first receptor antagonist to enter clinical trial was SU5416 [chemical name: 3-[(2,4-dimethylpyrrol-5yl)methylidenyl-indolin-2-one]. It is a potent, ATPcompetitive inhibitor, which selectively blocks VEGFinduced phosphorylation of Flk-1, displays potent antitumor activity in animals and induces endothelial cell apoptosis as well as tumor cell apoptosis $[92,93]$. It is regarded as a selective inhibitor $\left(\mathrm{K}_{i}\right.$ value $\left.=0.16 \mu \mathrm{M}\right)$ of $\mathrm{Flk}-1 / \mathrm{KDR}$ kinase activity [94], is 20 -fold less potent in inhibiting PDGF receptor phosphorylation in cells, is a weak inhibitor of FGF receptor $\left(\mathrm{K}_{i}=10.5 \mu \mathrm{M}\right)$, does not inhibit EGF receptor and has $\mathrm{IC}_{50}$ values around $10 \mu \mathrm{M}$ or more against IGF-1 receptor, Met, Src, Abl and Lck [68, 92, 94]. SU5416 potently blocks the KDR-mediated VEGF-dependent (but not FGF-dependent) proliferation of HUVECs $\left(\mathrm{IC}_{50}=40\right.$ $\mathrm{nM})$ and inhibits angiogenesis in vivo $[68,92]$. Consistently, it inhibits the growth of different tumor xenograft models, although it does not inhibit the proliferation of the same tumor cells in culture $[68,92]$.

SU5416 has a short (about $30 \mathrm{~min}$ ) plasma half-life in mice and rats [94] and has usually been administered daily; however, its efficacy was demonstrated also when given twice weekly [68]. The fact that SU5416 has a long-lasting biological effect despite its short plasma half-life and its competitive inhibition of Flk-1 tyrosine kinase activity, suggested this agent to be retained in the cell. Indeed, by using radiolabeled compound, it was demonstrated that human endothelial cells in vitro are capable of accumulating SU5416 so that inhibitory intracellular concentrations of this agent are maintained long after its removal from the medium [68]. This long-term inhibitory activity is probably due to the hydrophobic nature of SU5416, since less hydrophobic compounds (e.g., SU6668) do not show long-lasting activity or accumulation into the cells [68].

Another key element for this Flk-1 selective inhibitor is its ability to enhance, in animal models, radiation effect, with complete destruction of tumor blood vessels within 24 hours of treatment, and to reverse tumor resistance to radiotherapy [95]. Furthermore, SU5416, in a dosedependent manner, causes apoptosis in a c-Kit-positive human myeloid leukemia cell line (e.g., MO7E cells) and it has been successfully used to induce a stable remission in a 65 -year-old woman with refractory acute myeloid leukemia [96].

As a matter of fact, SU5416 is under clinical trials for Kaposi's sarcoma, lung cancer, colon and metastatic colorectal cancer, breast cancer and prostate cancer [51, 97, 98]. Phase I studies were performed on 69 advanced cancer patients treated i.v. twice weekly with SU 5416 (4.4 - 190 $\mathrm{mg} / \mathrm{m}^{2} /$ day): at the highest level, a dose limiting toxicity 
(projectile vomiting, mainly) was observed [99]. Despite its short plasma half-life, a twice-weekly i.v. administration of SU5416 resulted in an increased time to disease progression in patients with advanced malignancies and Kaposi's sarcoma [100, 101]. SU5416 has further advanced into Phase II/III trials at an initial recommended dose of $145 \mathrm{mg} / \mathrm{m}^{2}$, within the range of human maximally tolerated dose, and large studies have been planned to assess the efficacy of SU5416 (alone or in combination with standard anticancer therapy) in both colorectal cancer and NSCLC [51].

As tumor cells are known to produce different cytokines and growth factors and switch from the production of a given factor to another, selective inhibition of a single growth factor might allow only a partial control of tumor growth. This idea led to the development of SU6668, a less selective inhibitor with a more favorable pharmaceutical profile [102]. SU6668 inhibits VEGF, FGF-2 and PDGF tyrosine kinase receptors: it has a significantly lower $\mathrm{K}_{i}$ value for PDGF receptor $(8 \mathrm{nM})$ relative to $\operatorname{VEGF}(2.1 \mu \mathrm{M})$ and FGF $(1.2 \mu \mathrm{M})$ receptors [93, 102].

As SU5416, SU6668 has been found to be potent and effective in different cancer models with the advantage to be dosed orally. When administered per os (100-1600 $\mathrm{mg} / \mathrm{m}^{2} /$ day) to 16 patients with advanced malignancies, no dose-limiting toxicity was observed, although two patients at the highest dose presented liver abnormalities [103]. Sideeffects included nausea, headache, and fatigue [103].

Other inhibitors targeted to VEGFR include compounds from Astra Zeneca (ZD4190, ZD6474) and Novartis (PTK 787).

ZD4190 is a quinazoline-based compound which inhibits $\mathrm{KDR}\left(\mathrm{IC}_{50}=29 \mathrm{nM}\right)$ and Flt-1 $\left(\mathrm{IC}_{50}=708 \mathrm{nM}\right)$ and is much less potent in inhibiting FGF receptor (about 200-fold as compared to KDR); it is also 30 -fold more potent in inhibiting VEGF-induced endothelial cell proliferation $\left(\mathrm{IC}_{50}\right.$ $=50 \mathrm{nM})$ as compared to the FGF-induced one $\left(\mathrm{IC}_{50}=\right.$ $1530 \mathrm{nM}$ ) [104]. ZD6474 shows very promising preclinical results, as it induces significant regressions in PC-3 tumors of different size, being more effective in the largest tumors [105]. When used intermittently (one month withdrawal in treatment schedule), tumor re-growth could be stopped and regression was again observed in these tumors upon retreatment [105].

PTK 787 has an anilinophthalazine structure related to but distinct from the quinazoline derivatives described above [106]; it is a potent inhibitor of VEGF receptors ( IC $_{50}$ values are 37 and $77 \mathrm{nM}$, for KDR and Flt-1), inhibits, at submicromolar concentrations, PDGF receptor and c-Kit, but does not affect v-Abl, EGF receptor and FGF receptor [107]. PTK 787 also inhibits VEGF-induced KDR autophosphorylation, proliferation and enhances endothelial cell apoptosis [107]. This compound demonstrates an elevated anti-tumor and antiangiogenic activity in in vivo animal models as well as a good pharmacokinetic profile (it is active per os and reaches optimal plasmatic concentrations). Moreover, it seems to be more active in inhibiting tumor angiogenesis than in blocking normal angiogenesis, such as that of wound healing [107].

\section{Tyrosine Kinase Inhibitors of BCR-ABL}

The product of chromosome rearrangement $\mathrm{Bcr}-\mathrm{Abl}$ is not a receptor tyrosine kinase, because the catalytic portion of this molecule is a kinase of the cytosolic type. However, this oncoprotein shares the same localization with membrane receptors and has a constitutively activated kinase and therefore is examined here.

STI571 (Signal Transduction Inhibitor-571, formerly CGP57148B; imatinib mesylate; chemical structure: 4-[(4methyl-1- piperazinyl) methyl] - N-[4-methyl-3-[ [4-(3pyridinyl]- 2- pyrimidyl] amino] phenyl] benzamide methanesulfonate) is the first synthetic tyrosine kinase inhibitor to be approved $\left(\right.$ Glivec $^{R}$, Gleevec $\left.^{R}\right)$ for the therapy of Chronic Myeloid Leukemia (CML) and for gastrointestinal stromal tumors (May 2001 and February 2002, respectively) [108].

The main feature of CML is the presence of a specific chromosomal translocation [109] between the long arms of chromosomes 9 and 22, resulting in a shortened chromosome 22, commonly known as the Philadelphia (Ph) chromosome [110]. The molecular consequence of this translocation event is the fusion of the c-Abl oncogene (the human equivalent of $\mathrm{v}$-Abl, originally isolated from the genome of the Abelson murine leukemia virus [111]) from chromosome 9 to sequences of chromosome 22, the breakpoint cluster region (BCR), to give the chimeric BCRABL gene [112]. This gene encodes a fusion protein of variable size: $\mathrm{p} 185$ and $\mathrm{p} 210$ are the most frequent proteins, the latter being present in about $95 \%$ of patients with CML [113]. These fusion proteins have constitutive tyrosine kinase activity, which causes activation of intracellular pathways leading to profound alterations in proliferation, adhesion and survival of CML cells [114]. In vitro studies and studies in animal models clearly established that BcrAbl oncoprotein per se is sufficient to cause CML, and mutational analysis demonstrated that the tyrosine kinase activity of the protein is essential for its transforming ability [115 - 117].

Therefore, experimental researches were targeted to find a small molecule that could inhibit the Bcr-Abl tyrosine kinase activity and so obtain an effective and selective treatment for CML.

A phenylaminopyrimidine derivative, then called CGP 57148B (and later STI571), was able to occupy the kinase pocket in the Bcr-Abl protein and to block the access to ATP, so preventing the phosphorylation of substrate molecules [118 - 120]. Preclinical studies demonstrated that this molecule was very effective in blocking the tyrosine kinase activity of Bcr-Abl, the stem-cell factor receptor (cKit) and the PDGF receptor, but had little effect on other tyrosine kinases $[118,120]$. Moreover, STI571 blocked the growth and apoptosis in hematopoietic cells that express Bcr-Abl, but did not affect normal cells [118].

In a recently reported phase I clinical trial, STI571 was given orally (from 25 to $1000 \mathrm{mg} /$ day) to 83 patients with CML in the chronic phase in whom interferon- $\alpha$ treatment had failed [121]. The drug was well tolerated (the maximal tolerated dose could not be identified), the most common 
adverse effects being nausea, myalgia, edema and diarrhea. Complete hematological responses occurred in 53 out 54 patients treated with $300 \mathrm{mg}$ or more STI571, within one month from the beginning of therapy; $54 \%$ of patients treated with at least $300 \mathrm{mg} /$ day had cytogenetic responses occurring relatively rapidly [121].

A second dose-escalating study evaluated STI571 antitumor activity in 38 patients with myeloid blast crisis and 20 patients with acute lymphoblastic leukemia or lymphoid blast crisis [122]. They were treated orally with doses ranging from 300 to $1000 \mathrm{mg}$ /day. Side effects were similar to those reported in the first study; responses occurred in $55 \%$ of patients with myeloid blast crisis and $70 \%$ of patients with the two other conditions [122]. Unfortunately, almost all patients relapsed after a median time of 58 days, indicating that the responses in these clinical conditions are short lasting, at variance with what observed in chronic phase. In 11 patients with advanced CML who underwent disease progression after an initial response to STI571, reactivation of BCR-ABL signaling occurred always despite continued drug administration [123].

The mechanism of resistance was a consequence of mutation (in 6 patients a single aminoacid substitution in a threonine residue of the Abl kinase domain, which is known to form a critical hydrogen bond of the drug, was identified) or amplification (3 patients) of the target oncogene $\mathrm{Bcr}-\mathrm{Abl}$; one patient had both abnormalities [123]. As previously mentioned, STI571 inhibits also the tyrosine kinase activity of c-Kit (see also above), whose role in gastrointestinal stromal tumor is largely envisaged [124].

A recent case report showed an impressive tumor regression with STI571 $400 \mathrm{mg} /$ day in a patient with metastatic gastrointestinal stromal tumor, who had previously demonstrated inconsistent results to chemotherapy with different agents [125]. As mentioned above, on February 2002 the US Federal and Drug Administration approved STI571 for the treatment of gastrointestinal stromal cancers [108]; this suggests the usefulness of STI571 for a therapeutic approach of other malignancies, too.

More potent and highly selective RTK inhibitors, as well as phosphatase inhibitors/activators, will be developed in the next few years and we can anticipate that the drugs interfering with phosphorylation-mediated signaling pathways will become a major class of drugs for anticancer therapy.

\section{POSSIBLE NEW TARGETS FOR ANTICANCER THERAPY: THE MET RECEPTOR FAMILY}

In an attempt to identify new possible targets for anticancer therapy, different preclinical observations point to the Met receptor family as a likely candidate.

\section{The Met Receptor Family}

The Met receptor subfamily belongs to the RTK family of cell surface proteins and is composed by three members:
Met, the HGF/SF (Hepatocyte Growth Factor/Scatter Factor) receptor, Ron/Stk, the Macrophage Stimulating Protein (MSP) receptor $[126,127]$, and avian Sea, the chicken-MSP receptor [128].

The Met receptor family has some peculiar features. Its heterodimeric structure consists of a short extracellular $\alpha$ chain disulphide-linked to a longer transmembrane $\beta$-chain. These receptors are expressed as precursor single-chain molecule, proteolytically processed to generate the $\alpha / \beta$ heterodimer in the post-Golgi compartment by action of a furin-like convertase. Following ligand stimulation, two adjacent tyrosine residues in the activation loop, known as major phosphorylation site, become phosphorylated, resulting in an auto-catalytic activation of the receptor itself. Conversely, the biological activity of the receptors of the Met subfamily depends on a sequence of the carboxyterminal tail containing two phosphotyrosine residues, which act as multifunctional docking sites for $\mathrm{SH}$ containing effectors, activating an array of transduction pathways [129]. Moreover, the extracellular region of the $\beta-$ chain of Met family shares regions of homology with semaphorins and plexins, including Sema domain and the MRS (cysteine-rich Met-related sequence [130]). The RTK family of Met promotes a wide range of biological responses, ranging from cell growth and proliferation to differentiation, survival, migration and invasion.

\section{Met Structure and Signal Transduction}

The Met ligand is Hepatocyte growth factor (HGF), also known as scatter factor (SF). Both molecules were independently identified by their abilities to promote the proliferation of primary hepatocytes and dissociation/motility of epithelial cells, respectively [131, 132]. Molecular cloning of the cDNAs encoding both factors revealed their identity [133].

$\mathrm{HGF} / \mathrm{SF}$ is the prototype of a family that includes the macrophage stimulating protein (MSP), ligand of Ron/Stk and Sea RTKs. HGF/SF is a large heterodimeric protein, which shares sequence similarities with the serine-proteases of the coagulation cascade. It is secreted as single chain glycoprotein precursor and activated in the extracellular environment by specific proteases to form a $\alpha-\beta$ disulphidelinked heterodimer. The $\alpha$ subunit has a molecular weight of $62 \mathrm{kDa}$ and contains an amino-terminal hairpin loop and four typical kringle domains, similar to those found in the coagulation factors, which probably act as protein-protein interaction motifs. The $\alpha$ chain contains also the highaffinity binding site for Met and the low-affinity binding site for the heparan sulphate proteoglycans, whose effect seems to be the sequestration of HGF in the proximity of the producing cells, ensuring a local mechanism of action. The $32 / 34 \mathrm{kDa} \beta$ subunit is closely related to the catalytic domain of serine-proteases, but the serine residue involved in the catalysis is replaced by a tyrosine amino acid, abolishing its enzymatic activity.

Met tyrosine kinase receptor is a $190-\mathrm{kDa}$ transmembrane protein, composed of a $\alpha$ subunit of $50 \mathrm{kDa}$ disulphidelinked to a $\beta$ subunit of $145 \mathrm{kDa}$, which contains the 
catalytic activity [134]. Upon HGF binding and subsequent dimerization of Met, the receptor molecules undergo to in trans auto-phosphorylation in the cytoplasmic portion of the protein. Phosphorylation of tyrosine residues in the kinase domain $\left(\mathrm{Y}^{1234}\right.$ and $\mathrm{Y}^{1235}$ ), conserved among other RTKs, determines the activation of the enzymatic activity of the Met receptor. In particular, $\mathrm{Y}^{1235}$ constitutes the major phosphorylation site. Substitution of both residues with phenylalanine does not affect the receptor tyrosine kinase activity, but abolishes completely its biological effects [135].

The activation of the receptor leads to autophosphorylation of tyrosine residues of the intracellular portion, embedded in specific amino acid sequence, which acts as docking site for $\mathrm{SH} 2$ domain containing proteins. This sequence $\mathrm{Y}^{1349} \mathrm{VHVNATY}{ }^{1356} \mathrm{VNV}$ is responsible for the binding of various proteins, which include Grb2/Sos complex, pp60 ${ }^{\mathrm{c}-\mathrm{Src}}$, PI3-kinase, PLC- $\gamma$, Shc, Shp-2 and STAT3 [129, 136-139] and is therefore referred as Met multifunctional docking site. It was found that Grb2 is only recruited by $\mathrm{Y}^{1356}$, whereas the other proteins bind to both the tyrosine residues. The multifunctional docking site of Met is also able to interact with Gab1 (Grb2-associated binding protein), via a novel phosphotyrosine-binding domain (MBD or Met-binding domain) [140].

Conversely, in other cases Grb2 can serve to attenuate HGF receptor signaling, by enhancing receptor downregulation. Upon stimulation with HGF, the intracellular portion of the $\beta$-chain of Met is rapidly polyubiquitinated and degraded in a proteasome-dependent manner [141]. Met ubiquitination has been shown to be promoted by c-Cbl, an adapter protein involved in RTK downregulation through its E3 ligase activity. $\mathrm{Cbl}$ is able to interact to HGF receptor directly, through a juxtamembrane tyrosine residue $\left(\mathrm{Y}^{1003}\right)$, or indirectly via Grb2, involving the residue $\mathrm{Y}^{1356}$ of the C-terminal tail of Met [142]. The same residue $\mathrm{Y}^{1003}$ has been previously indicated to negatively regulate receptor activity through the binding of the protein tyrosine phosphatase PTP-S [143]. Another amino acid residue located in the juxtamembrane domain of Met and critical for negative regulation of the receptor is Ser985, which is a phosphorylation site for the protein kinase C [144].

The negative function of juxtamembrane domain is also demonstrated by experiments involving the constitutively activated version of the HGF receptor, Tpr-Met oncoprotein. In Tpr-Met, the regulatory juxtamembrane region is absent and replaced by spontaneously dimerising leucine zipper motif [145]. The transforming activity of Tpr-Met is postulated to reside both in the constitutive active form of the protein, due to dimerization motifs in Tpr sequence, and in the absence of residues $\mathrm{S}^{985}$ and $\mathrm{Y}^{1003}$, responsible for Met negative regulation.

\section{Met and Cancer}

In several epithelial tumors, including ovarian, pancreas, colorectal and thyroid carcinomas, HGF receptor is constitutively overexpressed and phosphorylated [146-150].
Notably, protein overexpression was found to be associated with amplification of Met gene in only a few primary carcinomas, but in a significant proportion of derived metastasis, suggesting a crucial role for the invasive properties of HGF receptor in promoting the metastatic spread of neoplastic cells. Increased expression and/or activity of the Met receptor have been associated with tumor development and possibly tumor metastasis [151, 152].

A direct genetic connection between Met activation and human cancer has been established by the identification of germline and somatic mutations in patients affected by papillary renal carcinoma [153]. All mutations were missense and located within the tyrosine kinase domain of the receptor, in a region termed activation loop. One possibility is that mutations affecting these residues might result in the displacement of the activation loop, increasing catalysis. Interestingly, three of the mutations (D1228N, $\mathrm{D} 1228 \mathrm{H}$ and $\mathrm{M} 1250 \mathrm{~T}$ ) are located in codons that are homologous to those mutated in the receptor tyrosine kinases c-Kit and Ret, causing mastocytosis with associated hematological disorders, and Multiple Endocrine Neoplasia type $2 \mathrm{~B}$, respectively.

In Ret receptor M918T mutation modifies a number of receptor properties, including substrate specificity, liganddependent activation, variation in the phosphorylation sites and the interaction of signal transducers [154]. It is possible that the homologous mutation M1250T will exert similar effects in Met. In the Kit model, mutations of D814, homologous to Met D1228, causes ligand independent activation of the receptor together with alteration of the substrate specificity [155].

Recently, it has been reported constitutive activation of the Met receptor in cells derived from patients of Malignant Mesothelioma (MM), an aggressive and invasive cancer, associated to previous exposure to asbestos fibers. Infection of human mesothelial cells by SV40 leads to a Tag-induced HGF autocrine circuit, mediated by Retinoblastoma protein interaction and inducing cell cycle progression into S-phase. This suggests a model of viral-related carcinogenesis, involving a RTK activation [156].

Recently, it has been reported a signaling adapter function for $\alpha 6 \beta 4$ integrin in the control of HGF-dependent invasive growth. Met selectively associates with $\alpha 6 \beta 4$ and following Met activation, the integrin becomes tyrosine phosphorylated and combines with Shc and PI3K, generating an additional signaling platform that potentiates HGF-triggered activation of Ras- and PI3K-dependent pathways. These data indicate a role for $\alpha 6 \beta 4$ in cancer invasion as a functional signal amplifier rather than an adhesive device [157].

\section{Downregulation of RTKs}

As stated above, for many aspects of cell behavior, it is important to start cellular signaling pathways as well as switching them off again and failures in the deactivation mechanisms often lead to cancer. Also RTKs must be 
inactivated, so that signaling evoked by growth factors can be arrested. One of the inactivation mechanisms consists in rapid clearance of the receptor from the surface, through receptor-mediated endocytosis and degradation of ligandreceptor complexes in the lysosome. During this process the $\mathrm{Cbl}$ adaptor protein, that binds to specific docking sites on activated RTKs via its SH2/PTB domain, is critical for the appropriate sorting of the receptors. $\mathrm{Cbl}$ recruits the enzymatic machinery responsible for ubiquitination of the receptor, a process that accelerates its endocytosis and delivery to lysosomes for degradation. [158].

It has been established that the degradation of EGF receptor, Neu/HER2 and Met (HGF receptor) are mediated by the ubiquitin-proteasome pathway [159-161].

Recently, two synchronized reports demonstrate that a complex made of $\mathrm{Cbl}$, the adaptor CIN85 and the enzyme endophilin, is recruited to tyrosine phosphorylated EGF receptor and HGF receptors, accelerating the termination of the biological activities of the two receptors [162, 163].

These results indicate for $\mathrm{c}-\mathrm{Cbl}$ and associated proteins a key role in sustaining an efficient downregulation of activated RTKs. They also suggest that, as a general mechanism, tethering oncogenic growth factor receptors to the endocytic degradation pathway may be an applicable approach for the suppression of transforming signaling pathways and offer novel potential targets for the treatment of malignancies.

\section{REFERENCES}

[1] Robertson, S.C., Tynan, J.A., Donoghue, D.J. Trends in Genetics, 2000, 16, 265.

[2] Schlessinger, J. Cell, 2000, 103, 211.

[3] Kossiakoff, A.A., De Vos, A.M. Adv. Protein Chem., 1998, $52,67$.

[4] Jiang, G., Hunter, T. Curr. Biol., 1999, 9, R568.

[5] Spivak-Kroizman, T., Lemmon, M.A., Dikic, I., Ladbury, J.E., Pinchasi, D., Huang, J., Jaye, M., Crumley, G., Schlessinger, J., Lax, I. Cell, 1994, 79, 1015.

[6] Lyon, M., Deakin, J.A., Mizuno, K., Nakamura, T., Gallagher, J.T. J. Biol. Chem., 1994, 269, 11216.

[7] Hubbard, S.R., Till, J.H. Annu. Rev. Biochem., 2000, 69 , 373.

[8] Hubbard, S.R., Wei, L., Ellis, L., Hendrickson, W.A. Nature, 1994, 372, 746.

[9] Hubbard, S.R. EMBO J., 1997, 16, 5572.

[10] Ahmed, Z., Smith, B.J., Pillay, T.S. FEBS Lett., 2000, 67, 199.

[11] Mohammadi, M., Schlessinger, J., Hubbard, S.R. Cell, 1996, 86, 577.
[13] Treisman, R. Curr. Opin. Cell Biol., 1996, 8, 205.

[14] Jin, M.H., Sawamoto, K., Ito, M., Okano, H. Mol. Cell. Biol., 2000, 20, 2098-2107.

[15] Cochet, C., Gill, G.N., Meisenhelder, J., Cooper, J.A., Hunter, T. J. Biol. Chem., 1984, 259, 2553.

[16] Hilton, D.J., Richardson, R.T., Alexander, W.S., Viney, E.M., Wilson, T.A., Sprigg, N.S., Starr, R., Nicholson, S.E., Metcalf, D., Nicola, N.A. Proc. Natl. Acad. Sci. USA, 1998, 95,114 .

[17] Oestman, A., Boehmer, F.D. Trends in Cell Biol., 2001, 11, 258.

[18] Di Fiore, P.P., Gill, G.N. Curr. Opin. Cell Biol., 1999, 11, 483.

[19] Hunter, T. Cell, 2000, 100, 113.

[20] Woodburn, J.R. Pharmacol. Ther., 1999, 82, 241.

[21] Voldborg, B.R., Damstrup, L., Spang-Thomsen, M., Poulsen, H.S. Ann. Oncol., 1997, 8, 1197.

[22] Chen, K., Ke, L.D., Yuan, X.H., Adler-Storthz, K. Anticancer Res., 2000, $20,899$.

[23] Bogdan, S., Klaembt, C. Curr. Biol., 2002, 10, R292.

[24] Moscatello, D.K., Holgado-Madruga, M., Emlet, D.R., Montgomery, R.G., Wong, A.J. J. Biol. Chem., 1998, 273, 200 .

[25] Mendelsohn, J., Baselga, J. Oncogene, 2000, 19, 6550.

[26] Ciardiello, F. Drugs, 2000, 60 (Suppl. 1), 25.

[27] Shao, Z.M., Wu, J., Shen, Z.Z., Barsky, S.H. Cancer Res., 1998, 58,4851 .

[28] Uckun, F.M., Narla, R.K., Zeren, T., Yanishevski, Y., Myers, D.E., Waurzyniak, B., Ek, O., Schneider, E., Messinger, Y., Chelstrom, L.M., Gunther, R., Evans, W. Clin. Cancer Res., 1998, 4, 1125.

[29] Ferry, D.R., Smith, A., Malkhandi, J., Fyfe, D.W., de Takats, P.G., Anderson, D., Baker, J., Kerr, D.J. Clin. Cancer Res., 1996, 2, 659 .

[30] Ciardiello, F., Tortora, G. Clin. Cancer Res., 2001, 7, 2958.

[31] Arteaga, C.L., Johnson, D.H. Curr. Opin. Oncol., 2001, 13, 491.

[32] Ciardiello, F., Caputo, R., Damiano, V., Pomatico, G., De Placido, S., Fan, Z., Bianco, A.R., Tortora, G. Clin. Cancer Res., 2000, 6, 2053.

[33] Woodburn, J.R., Kendrew, J., Fennell, M., Wakeling, A.E. Proc. Annu. Meet.Am. Assoc. Cancer Res., 2000, 41, 402.

[34] Sirotnak, F.M., Zakowski, M.F., Miller, V.A., Scher, H.I., Kris, M.G. Clin. Cancer Res., 2000, 6, 4885.

[35] Barton, J., Blackledge, G., Wakeling, A. Urology, 2001, 58 (Suppl 2A), 114.

[12] Heldin, C.H. Stem Cells, 2001, 19, 295. 
[36] Arteaga, C.L., Ramsey, T.T., Shawer, L.K., Guyer, C.A. J. Biol. Chem., 1997, 272, 23247.

[37] Lichtner, R. B., Menrad, A., Sommer, A., Klar, U., Schneider, M.R. Cancer Res., 2001, 61, 5790.

[38] Hidalgo, M., Siu, L.L., Nemunaitis, J., Rizzo, J., Hammond, L.A., Takimoto, C., Eckhardt, S.G., Tolcher, A., Britten, C.D., Denis, L., Ferrante, K., Van Hoff, D.D., Silberman, S., Rowinsky, E.K. J. Clin. Oncol., 2001, 19, 3267.

[39] Shin, D.M., Nemunaitis, J., Zinner, R.G., Donato, N., Shin, H.J., Myers, J., Zhang, P., Zengraft, R., Khuri, F.R., Glisson, B.S., Eiseman, I., Olson, S., Bycott, P., Lenehan, P., Hong, W.K. Proc. Am. Soc. Clin. Oncol., 2001, 21, 82.

[40] Nelson, J.M., Fry, D.W. J. Biol. Chem., 2001, 276, 14842.

[41] Bruns, C.J., Solorzano, C.C., Harbison, M.T., Ozawa, S., Tsan, R., Fan, D., Abbruzzese, J., Traxler, P., Buchdunger, R., Fidler, I.J. Cancer Res., 2000, 60, 2926.

[42] Solorzano, C.C., Baker, C.H., Tsan, R., Traxler, P., Cohen, P., Buchdunger, E., Killion, J.J., Fidler, I.J. Clin. Cancer Res., 2001, 7, 2563.

[43] Rusnak, D.W., Affleck, K., Cockerill, S.G., Stubberfield, C., Harris, R., Page, M., Smith, K.J., Guntrip, S.B., Carter, M.C., Shaw, R.J., Jowett, A., Stables, J., Topley, P., Wood, E.R., Brignola, P.S., Kadwell, S.H., Reep, B.R., Mullin, R.J., Alligood. K.J., Keith, B.R., Crosby, R.M., Murray, D.M., Knight, W.B., Gilmer, T.M., Lackey, K. Cancer Res., 2001, 61, 7196 .

[44] Heldin, C.H., Westermark, B. Physiol. Rev., 1999, 79, 1283.

[45] Heldin, C.H., Eriksson, U., Ostman, A. Arch. Biochem. Biophys., 2002, 398, 284.

[46] Robbins, K.C., Antoniades, H.N., Devare, S.G., Hunkapiller, M.W., Aaronson, S.A. Nature, 1983, 305, 605 .

[47] Ostman, A., Andersson, M., Hellman, U., Heldin, C.H. J. Biol. Chem., 1991, 266, 10073.

[48] Leal, F., Williams, L.T., Robbins, K.C., Aaronson, S.A. Science, 1985, 230, 327.

[49] Beckmann, M.P., Betsholtz, C., Heldin, C.H., Westermark, B., Di Marco, E., Di Fiore, P.P., Robbins, K.C., Aaronson, S.A. Science, 1988, 241, 1346.

[50] Sebti, M.S., Hamilton, A.D. Oncogene, 2000, 19, 6566.

[51] Morin, M.J. Oncogene, 2000, 19, 6574.

[52] George, D. Semin. Oncol., 2001, 28, 27.

[53] Cohen, S., Smolen, J., Emery, E., Cannon, G., Weaver, A., Schiff, M. Arthr. Rheum., 2000, 43, 1221.

[54] Mattar, T., Kochhar, K., Bartlett, R., Bremer, E.G., Finnegan, A. FEBS Lett., 1993, 334, 161.

[55] Xu, X., Williams, J.W., Bremer, E.G., Finnegan, A., Chong, A.S. J. Biol. Chem., 1995, 270, 12398.

[56] Shawver, L.K., Schwarz, D.P., Mann, E., Chen, H., Tsai, J., Chu, L., Taylor, A., Longhi, M., Meredith, S., Germain, L.,
Jacobs, J.S., Tang, C., Ullrich, A., Berens, M.F., Hersch, E., McMahon, G., Hirth, K.P., Powell, T.J. Clin. Cancer Res., 1997, 3, 1167.

[57] Ghosh, S., Narla, R.K., Zheng, Y., Liu, X.P., Jun, X., Mao, C., Sudbeck, E.A., Uckun, F.M. Anticancer Drug Des., 1999, 14, 403.

[58] Hamilton, L.C., Vojnovic, I., Warner, T.D. Br. J. Pharmacol., 1999, 127, 1589.

[59] Eckhardt, S.G., Rizzo, J., Sweeney, K.R., Cropp, G., Baker, S.D., Kraynak, M.A., Kuhn, J.G., Villalona-Calero, M., Hammond, L., Weiss, G., Thurman, A., Smith, L., Drengler, R., Eckhardt, J.R., Moczygemba, J., Hannah, A.L., von Hoff, D.D., Rowinsky, E.K. J. Clin. Oncol., 1999, 17, 1095.

[60] Blaskovitch, M.A., Lin, Q., Delarue, F.L., Sun, J., Park, H.S., Coppola, D., Hamilton, A.D., Sebti, S.M. Nat. Biotechnol., 2000, 18, 1065.

[61] Muller, Y.A., Li, B., Christinger, H.W., Wells, J.A., Cunningham, B.C., de Vos, A.M. Proc. Natl. Acad. Sci. USA, 1997, 94, 7192.

[62] Campion, S.R., Niyogi, S.K. Progr. Nucl. Acid Res. Mol. Biol., 1994, 49, 353.

[63] Ikeda, H., Kanakura, Y., Tamaki, T. Kuriu, A., Kitayama, H., Ishikawa, J., Kanayama, Y., Yonezawa, T., Tarui, S., Griffin, J.D. Blood, 1991, 78, 2962.

[64] Zsebo, K.M., Williams, D.A., Geissler, E.N., Broudy V.C., Martin, F.H., Atkins, H.L., Hsu, R.Y., Birkett, N.C., Okin, K.H., Murdock, D.C. Cell, 1990, 63, 213.

[65] Broudy, V.C. Blood, 1997, 90, 1345.

[66] Krystal, G.W., Honsawek, S., Kiewlich, D., Liang, C., Vasile, S., McMahon, G., Lipson, K.E. Cancer Res., 2001, 61,3660 .

[67] Smolich, B.D., Yuen, H.A., West, K.A., Giles, F.J., Albitar, M., Chererington, J.M. Blood, 2001, 97, 1413.

[68] Mendel, D.B., Laird, D.A., Smolich, B., Blake, R.A., Liang, C., Hannah, A.L., Shaheen, R., Ellis, L.M., Weitman, S., Shawver, L.K., Cherrington, J.M. Anticancer Drug Design, 2000, 15, 29.

[69] Ma, Y., Carter, E., Wang, X., McMahon, G., Longley, B.J. J. Invest. Dermatol., 2000, 114, 392.

[70] Krystal, G.W., Carlson, P., Litz, J. Cancer Res., 1997, 57, 2203

[71] Levis, M., Tse, K.F., Smith, B.D., Garrett, E., Small, D. Blood, 2001, 98, 885 .

[72] Buchdunger, E., Zimmermann, J., Mett, H., Meyer, M., Muller, M., Bruker, B.J., Lydon, N.B. Cancer Res., 1996, $56,100$.

[73] Krystal, G.W., Honsawek, S., Litz, J., Buchdunger, E. Clin. Cancer Res., 2000, 6, 3319.

[74] Heinrich, M.C., Griffith, D.J., Drucker, B.J., Wait, C.L., Ott, K.A., Ziegler, A.J. Blood, 2000, 96, 925.

[75] Ashmann, L.K. Int. J. Biochem. Cell Biol., 1999, 31, 1037. 
[76] Sungaran, R., Chislom, O.T., Markovic, B., Khachigian, L.M., Tanaka, Y., Chong, B.H. Blood, 2000, 95, 3094.

[77] Sun, L., Tran, N., Tang, F., App, H., Hirth, P., McMahon, G., Tang, C. J. Med. Chem., 1998, 41, 2588.

[78] Sun, L., Tran, N., Liang, C., Tang, F., Rice, A., Schreck, R., Waltz, K., Shawver, L.K., McMahon, G., Tang, C. J. Med. Chem., 1999, 42, 5120.

[79] Veikkola, T., Alitalo, K. Semin. Cancer Biol., 1999, 9, 211.

[80] Liekens, S., De Clerq, E., Neyts, J. Biochem. Pharmacol., 2001, 61, 253 .

[81] Mukhopadhyay D., Tsiokas, L., Zhou, X.M., Foster, D., Brugge, J.S., Sukhatme, V.P. Nature, 1995, 375, 577.

[82] Richard, D.E., Berra, E., Pouyssegur, J. Biochem. Biophys. Res. Commun., 1999, 266, 718.

[83] Waltenberger, J., Mayr, U., Pentz, S., Hombach, V. Circulation, 1996, 94, 1647.

[84] Neufeld, G., Cohen, T., Gengrinovitch, S., Poltorak, Z. FASEB J., 1999, 13, 9.

[85] Barleon, B., Sozzani, S., Zhou, D., Weich, H.A., Mantovani, A., Marme, D. Blood, 1996, 87, 3336.

[86] Oyama, T., Ran, S., Ishida, T., Nadaf, S., Kerr, L., Carbone, D.P., Gabrilovich, D.I. J. Immunol., 1998, 160, 1224.

[87] Folkman, J. Nat. Med., 1995, 1, 27.

[88] Zhu, Z., Witte, L. Investig. New Drugs, 1999, 17, 195.

[89] Takano, S., Yoshii, Y., Kondo, S., Suzuki, H., Maruno, T., Shirai, S., Nose, T. Cancer Res., 1996, 56, 2185.

[90] Millauer, B., Shawver, L.K., Plate, K.H., Risau, W., Ullrich, A. Nature, 1994, 367, 576.

[91] Millauer, B., Longhi, P.M., Plate, K.H., Shawver, L.K., Risau, W., Ullrich, A., Strawn, L.M. Cancer Res., 1996, 56, 1615.

[92] Fong, T.A., Shawver, L.K., Sun, L., Tang, C., App, H., Powell, T.J., Kim, Y.H., Screck, R., Wang, X., Risau, W., Ullrich, A., Hirth, K.P., McMahon, G. Cancer Res., 1999, 59, 99.

[93] Shaheen, R.M., Davis, D.W., Liu, W., Zebrowski, B.K., Wilson, M.R., Bucana, C.D., McConkey, D.J., McMahon, G., Ellis, L.M. Cancer Res., 1999, 59, 5412.

[94] Mendel, D.B., Screck, R.E., West, D.C., Li, G., Strawn, L.M., Tanciongco, S.S., Vasile, S., Shawver, L.K., Cherrington, J.M.Clin. Cancer Res., 2000, 6, 4848.

[95] Geng, L., Donnelly, E., McMahon, G., Lin, C., Sierra.Rivera, E., Oshinka, H., Hallahan, D.E. Cancer Res., 2001, 61, 2413.

[96] Mesters, R.M., Padro, T., Bieker, R., Steins, M., Goner, M., Kelsey, S., Scigalla, P., Fiedler, W., Buchner, T., Berdel, W.E. Blood, 2001, 98, 241.

[97] Brower, T. Nature Biotecnol., 1999, 17, 963.
[98] Takamoto, T., Sasaki, M., Kuno, T., Tamaki, N. Kobe J. Med. Sci., 2001, 47, 181.

[99] Rosen, L., Mulay, M., Mayers, A., Kabbinavar, F., Rosen, P., Cropp, G., Hannah, A. Proc. Am. Soc. Clin. Oncol., 1999, 18, 618 .

[100] Rosen, L., Kabbinavar, F., Rosen, P., Mulay, M., Cropp, G., Hannah, A.L. Proc. Am. Soc. Clin. Oncol., 1998, 17, 218.

[101] Gill, P., Arasteh, K., Jacobs, M., Friedman-Kien, A., Miles, A., Hannah, A., Langecker, P. Intersci. Conf. Antimicrob.Agents Chemother., 1999, (Abstr) 490.

[102] Laird, A.D., Vajkoczy, P., Shawver, L.K., Thurnher, A., Liang, C., Mohammadi, M., Schlessinger, J., Ullrich, A., Hubbard, S.R., Blake, R.A., Fong, T.A., Strawn, L.M., Lun, L., Tang, C., Hawtin, R., Tang, F., Shenoy, N., Hirth, K.P., MacMahon, G., Cherrington, G.L. Cancer Res., 2000, 60, 4152 .

[103] Rosen, L., Hannah, A., Rosen, P., Kabbinavar, F., Mulay, M., Gicanov, N., De Paoli, A., Cropp, G., Mabry, M. Proc. Am. Soc. Clin. Oncol., 2000, 19, 708.

[104] Wedge, S.R., Ogilvie, D.J., Dukes, M., Kendrew, J., Curwen, J.O., Hennequin, F., Thomas, A.P., Stokes, E.S.E., Curry, B., Richmond, G.H.P., Curry, B. Cancer Res., 2000, 60, 970.

[105] Wedge, S.R., Ogilvie, D.J., Dukes, M., Kendrew, J., Hennequin, F., Stokes, E.S.E., Curry, B. Proc. Am. Assoc. Cancer Res., 2000b, 41, 3610.

[106] Bold, G., Altmann, K.H., Frei, J., Lang, P.W., Traxler, P. Wietfeld, B., Bruggen, J., Buchdunger, E., Cozens, R., Ferrari, S., Furet, P., Hofmann, F., Martiny-Baron, G., Mestan, J., Rosel, J., Sills, M., Stover, D., Acemoglu, F., Boss, E., Emmenegger, R., Lasser, L., Masso, E., Roth, R., Schlachter, C., Vetterli, W. J. Med. Chem., 2000, 43, 2310.

[107] Wood, J.M., Bold, G., Buchdunger, E., Cozens, R., Ferrari, S., Frei, J., Hofmann, F., Meslan, J., Mett, H., O'Reilly, T., Persohn, E., Rosel, J., Schnell, C., Stover, D., Theuer, A., Towbin, H., Wenger, F., Woods-Cook, K., Menrad, A., Siemeister, G., Schimer, M., Thierauch, K.H., Schneider, M.R., Drevs, J., Martiny-Baron, G., Totzke, F. Cancer Res., 2000, 60, 970 .

[108] Savage, D.G., Antman, K.H. New Engl. J. Med., 2002, 346, 683.

[109] Rowley, J.D. Nature, 1973, 243, 290.

[110] Nowell, P.C., Hungerford, D.A. Science, 1960, 132, 1497.

[111] Abelson, H.T., Rabstein, L.S. Cancer Res., 1995, 30, 2213.

[112] Shtivelman, E., Lifshitz, B., Gale, R.P., Canaani, E. Nature, 1985, 315, 550 .

[113] O’Dwyer, M.E., Druker, B.J. J. Intern. Med., 2001, $250,3$.

[114] Faderl, S., Talpaz, M., Estrov, Z., Kantarjian, H.M. Ann. Intern. Med., 1999, 131, 207.

[115] Daley, G.Q., Van Etten, R.A., Baltimore, D. Science, 1990, $247,824$.

[116] Heisterkamp, N., Jenster, G, ten Hoeve, J., Zovich, D., Pattengale, P.K., Groffen, J. Nature, 1990, 344, 251. 
[117] Lugo, T.G., Pendergast, A.M., Muller, A.J., Witte, O.N. Science, 1990, 247, 1079.

[118] Druker, B.J., Tamura, S., Buchdunger, E., Ohno, S., Segal, G.M., Fanning, S., Zimmermann, J. Lydon, N.B. Nat. Med., 1996, 2, 561.

[119] Deininger, M.W., Goldman, J.M., Lydon, N., Melo, J.V. Blood, 1997, 90, 3691

[120] Druker, B.J., Lydon, N.B. J. Clin. Invest., 2000, 105, 3.

[121] Druker, B.J., Talpaz, M., Resta, D.J., Peng, B., Buchdunger, E., Ford, J.M., Lydon, N.B., Kantarjian, H., Capdeville, R., Ohno-Jones, S., Sawyers, C.L. New Engl. J. Med., 2001, $344,1031$.

[122] Druker, B.J., Sawyers, C.L., Kantarjian, H., Resta, D.J., Reese, S.F., Ford, J.M., Capdeville, R., Talpaz, M. New Engl. J. Med., 2001, 344, 1038.

[123] Gorre, M.E., Mohammed, M., Ellwood, K., Hsu, N., Paquette, R., Rao, P.N., Sawyers, C.L. Science, 2001, 293, 876.

[124] Hirota, S., Isozaki, K., Moriyama, Y., Hashimoto, K., Nishida, T., Ishiguro, S., Kawano, K., Hanada, A., Takeda, M., Muhammad Tunio, G., Matsuzawa, Y., Kanakura, Y., Shinomura, Y., Kiamura, Y. Science, 1998, 279, 577.

[125] Joensuu, H., Roberts, P.J., Sarlomo-Rikala, M., Andersson, L.C., Tervahartiala, P., Tuveson, D., Silberman, S.L., Capdeville, R., Dimitrijevic, S., Druker, B., Demetri, G.D. New Engl. J. Med., 2001, 344, 1052.

[126] Gaudino, G., Follenzi, A., Naldini, L., Collesi, C., Santoro, M., Gallo, K.A., Godowski, P.J., Comoglio, P.M. EMBO J., 1994, 13, 3524.

[127] Wang, M.H., Ronsin, C., Gesnel, M.C., Coupey, L., Skeel, A., Leonard, E.J., Breathnach, R. Science, 1994, 266, 117.

[128] Wahl, R.C., Hsu, R-Y, Hsu, J.L., Jelinek, M.A., Chen, K., Courchesne, P., Patterson, S.D., Parsons, J.T., Welcher, A.A. J. Biol. Chem., 1999, 274, 26361.

[129] Ponzetto, C., Bardelli, A., Zhen, Z., Maina, F., dalla Zonca, P., Giordano, S., Graziani, A., Panayotu, G., Comoglio, P.M. Cell, 1994, 77, 261.

[130] Tamagnone, L., Astigiani, S., Chen, H., He, Z., Ming, G.I., Song, H., Chedotal, A., Winberg, M.L., Goodman, C.S., Poo, M., Tessier-Lavigne, M., Comoglio, P.M. Cell, 1999, 99, 71.

[131] Nakamura, T., Teramoto, H., Ichihara, A. Proc. Natl. Acad. Sci. USA, 1986, 83, 6489.

[132] Stoker, M., Gherardi, E., Perryman, M., Gray, J. Nature, 1987, 32, 239.

[133] Weidner, K.M., Behrens, J., Vandekerckhove, J., Birchmaier, W. J. Cell. Biol., 1990, 111, 2097.

[134] Giordano, S., Ponzetto, C., Di Renzo, M.F., Cooper, C.S., Comoglio, P.M. Nature, 1989, 339, 155.

[135] Longati, P., Bardelli, A., Ponzetto, C., Naldini, L., Comoglio, P.M. Oncogene, 1994, 9, 49.
[136] Pelicci, G., Giordano, S., Zhen, Z., Salcini, A.E., Lanfrancone, L., Bardelli, A., Panayotou, G., Waterfield, M.D., Ponzetto, C., Pelicci, P.G., Comoglio, P.M. Oncogene, 1995, 10, 1631.

[137] Fournier, T.M., Kamikura, D., Teng, K., Park, M. J. Biol. Chem., 1996, 271, 22211.

[138] Nguyen, L., Holgado-Madruga, M., Maroun, C., Fixman, E.D., Kamikura, D., Fournier, T., Charest, A., Tremblay, M.L., Wong, A.J., Park, M. J. Biol. Chem., 1997, 272, 20811.

[139] Boccaccio, C., Ando, M., Tamagnone, L., Bardelli, A., Michieli, P., Battistini, C., Comoglio, P.M. Nature, 1998, 391, 285.

[140] Weidner, K.M., Di Cesare, S., Sachs, M., Brinkmann, V., Behrens, J., Birchmeier, W. Nature, 1996, 38, 173.

[141] Jeffers, M., Taylor, G.A., Weidner, K.M., Omura, S., Vande Woude, G.F. Mol. Cell. Biol., 1997, 17, 799.

[142] Peschard, P., Fournier, T.M., Lamorte, L., Naujokas, M.A., Band, H., Langdon, W.Y., Park, M. Mol. Cell, 2001, 8, 995.

[143] Villa-Moruzzi, E., Puntoni, F., Bardelli, A., Vigna, E., De Rosa, S., Comoglio, P.M. Biochem. J., 1998, 336: 235.

[144] Gandino, L., Longati, P., Medico, E., Prat, M., Comoglio, P.M. J. Biol. Chem., 1994, 269, 1815.

[145] Rodrigues, G.A., Park, M. Mol. Cell. Biol., 1993, 13, 6711.

[146] Prat, M., Narsimhan, R.P., Crepaldi, T., Nicotra, M.R., Natali, P.G., Comoglio, P.M. Int. J. Cancer, 1991, 49, 323.

[147] Rong, S., Jeffers, M., Resau, J.H., Tsarfaty, I., Oskarsson, M., Vande Woude, G.F. Cancer Res., 1993, 53, 5355.

[148] Liu, N., Furukawa, T., Kobari, M., Tsao, M-S., Am. J. Path., 1998, 153, 263.

[149] Di Renzo, M.F., Poulsom, R., Olivero, M., Comoglio, P.M., Lemoine, N.R. Cancer Res., 1994, 55, 1129.

[150] Di Renzo, M.F., Olivero, M., Katsaros, D., Crepaldi, T., Gaglia, P., Zola, P., Sismondi, P., Comoglio, P.M. Int. J. Cancer, 1995, 58, 658.

[151] Jiang, W., Hiscox, S., Matsumoto, K., Nakamura, T. Crit. Rev. Oncol. Hematol., 1999, 29, 209.

[152] Stuart, K.A., Riordan, S.M., Lidder, S., Crostella, L., Williams, R., Skouteris, G.G. Int. J. Exp. Pathol., 2000, 81, 17.

[153] Schmidt, L., Duh, F.M., Chen, F., Kishida, T., Glenn, G., Choyke, P., Scherer, S.W., Zhuang, Z., Lubensky, I., Dean, M., Allikmets, R., Chidambaram, A., Bergerheim, U.R., Feltis, J.T., Casadevall, C., Zamarron, A., Bernues, M., Richard, S., Lips, C.J., Walther, M.M., Tsui, L.C., Geil, L., Orcutt, M.L., Stackhouse, T., Lipan, J., Slife, L., Brauch, H., Decker, J., Niehans, G., Hughson, M.D., Moch, H., Storkel, S., Lerman, M.I., Linehan, W.M., Zbar, B. Nature Genet., 1997,16, 68 .

[154] Santoro, M., Carlomagno, F., Romano, A., Bottaro, D.P., Dathan, N.A., Grieco, M., Fusco, A., Vecchio, G., Matoskova, B., Kraus, M.H., Di Fiore, P.P. Science, 1995, 267,381 . 
[155] Tsujimura, T., Furitsu, T., Morimoto, M., Isozaki, K., Nomura, S., Matsuzawa, Y., Kitamura, Y., Kanakura, Y, Blood, 1994, 83, 2619.

[156] Cacciotti, P., Libener, R., Betta, P., Martini, F., Porta, C., Procopio, A., Strizzi, L., Penengo, L., Tognon, M., Mutti, L., Gaudino, G. Proc. Natl. Acad. Sci. USA, 2001, 98, 12032 .

[157] Trusolino, L., Bertotti, A., Comoglio, P.M. Cell, 2001, 107,643 .

[158] Waterman, H., Yarden, Y. FEBS Lett., 2001, 490, 142.

[159] Levkowitz, G., Waterman, H., Ettenberg, S.A., Katz, M., Tsygankov, A.Y., Alroy, I., Lavi, S., Iwai, K., Reiss, Y.,

\section{RELATED ARTICLES RECENTLY PUBLISHED IN CURRENT PHARMCEUTICAL DESIGN}

Adjei, A. A. Signal transduction pathway targets for anticancer drug discovery. Curr. Pharm. Des. 2000, 6(4), 361-78.

Botta, M.; Manetti, F. and Corelli, F. Fibroblast growth factors and their inhibitors. Curr. Pharm. Des. 2000, 6(18), 1897-924.

Fretz, H.; Furet, P.; Garcia-Echeverria, C.; Schoepfer, J. and Rahuel, J. Structure-based design of compounds inhibiting Grb2-SH2 mediated protein-protein interactions in signal transduction pathways. Curr. Pharm. Des. 2000, 6(18), 1777-96.
Ciechanover, A., Lipkowitz, S., Yarden, Y. Mol. Cell, 1999, $4,1029$.

[160] Levkowitz, G., Oved, S., Klapper, L.N., Larari, D., Lavi, S., Sela, M., Yarden, Y. J. Biol. Chem., 2000, 275, 35532.

[161] Jeffers, M., Taylor, G.A., Weidner, K.M., Omura, S., Vande Woude, G.F. Mol. Cell. Biol., 1997, 17, 799.

[162] Soubeyran, P., Kowanetz, K., Szymkiewicz, J., Langdon, W.Y., Dikic, I. Nature, 2002, 416, 183.

[163] Petrelli, A., Gilestro, G.F., Lanzardo, S., Comoglio, P.M., Migone, N., Giordano, S. Nature, 2002, 416, 187, 
Copyright $\odot 2003$ EBSCO Publishing 